https://doi.org/10.18485/iipe_euchanges.2021.ch21

\title{
WHAT IS THE ROLE OF THE EUROPEAN UNION IN RESHAPING THE FUTURE OF THE WORLD TRADE ORGANIZATION?
}

\begin{abstract}
Sanja JELISAVAC TROŠIĆ ${ }^{1}$
Abstract: The crisis of the regulatory framework of international trade has become more pronounced. Trade policy tensions between the US, the EU and China have evolved and could continue for long unless there is a reform of the international trade framework. The future of the WTO as an intergovernmental institution that regulates international trade practices is uncertain due to this unprecedented economic turmoil and political tensions. The EU is a key supporter of the multilateral trading system and seeks to address the challenges that the WTO faces by proposing a set of concrete reform proposals. The European Commission announced its intention to lead reforms of the WTO. In this paper, we will explore the EU's position on WTO reform and compare the EU's position with the position of other powerful countries with influence in the WTO. According to the findings, the EU is seeking to take the lead in redefining the WTO. Compared to other WTO members, the EU is particularly active and comprehensive in proposing modernization and reform of the WTO.
\end{abstract}

Keywords: EU, WTO reform, crisis, trade, US, China.

\footnotetext{
${ }^{1}$ Senior Research Fellow, Institute of International Politics and Economics, E-mail: sanja@diplomacy.bg.ac.rs

The paper presents findings of a study developed as a part of the research project "Serbia and challenges in international relations in 2021", financed by the Ministry of Education, Science, and Technological Development of the Republic of Serbia, and conducted by Institute of International Politics and Economics, Belgrade.
} 


\section{INTRODUCTION}

The World Trade Organization (WTO) provides a framework for negotiating trade agreements and facilitates the process of resolving trade disputes. The system is set up so that trade disputes are resolved by independent judges through the WTO dispute settlement mechanism. The WTO membership has expanded to 164 members, representing over 98\% of international trade. Since the crisis of neoliberalism started, the WTO, as a key international trade organization, has been put into a vulnerable position (Chorev, Babb, 2009, p. 460). The trade war between the United States of America (US) and China, which escalated in 2018 and 2019, should have been addressed and possibly solved through the WTO's multilateral trade system (Ciuriak, 2019, p. 132). In Trump's US presidency, protectionism and nationalism played a central role, and appointments to the WTO Appellate Body have been blocked and complaints have been filed about the use of lawsuits and litigation instead of negotiations. The US was the leading country to contribute to the stalemate in the 2017 WTO negotiations in Buenos Aires by blocking a draft ministerial text, which includes a reference to the central role of the global trading system and trade as a flywheel of the world's development. In 2015, the WTO reached a significant milestone with the receipt of its 500th trade dispute for settlement. Trade disputes are becoming more complex, and the Appellate Body must make a decision in a short time frame, taking into account the growing law. In dispute settlement, the WTO suffered a setback at the end of 2019 when the members could not agree on reforms for the Appellate Body. Currently, the Appellate Body cannot review appeals since the term of the last sitting Appellate Body member expired on 30 November 2020 (WTO, 2021). It is now clear that dispute settlement reform will have to be a result of the agreement between the high political levels of the most influential countries, primarily the European Union (EU) and the US.

The Doha Round of multilateral negotiations has been troubled almost from the beginning. Longstanding differences over agriculture policies, disagreement between the most influential WTO members, a large number of issues and topics for negotiations raised but not finished, along with the principle of the "single undertaking", as well as other factors, such as serious problems in the functioning of the dispute settlement system and the increase in unilateral protectionists trade measures introduced by the most powerful economies of the world, led to the fact that countries individually began to seek changes in the system of functioning of the WTO. The crisis has even penetrated to the highest ranks of this organization. Roberto 
Azevêdo stepped down as the WTO Director-General on 31 August 2020, a year before the expiry of his mandate. Nigeria's Ngozi Okonjo-Iweala was slated to be the new Director-General since she had won support from the vast majority of the member states, including the EU, Japan and China, but not the US. The General Council meeting scheduled for 9 November 2020 to consider the appointment of the next WTO Director-General has been postponed until further notice.

We are now witnessing the reshaping of the global economic and political order. In order to overcome trade tensions, it is imperative to reform the multilateral trade framework. It is important to understand that the issues are larger than the conflict between the US and China and that a modern multilateral framework must be created in which all countries have a mutual stake in ensuring its integrity.

The aim of this research is to improve knowledge on this important topic and determine in which direction the EU proposal to modernize the WTO is going. The aim, as well, is to compare the proposals and positions of the EU with other countries that are the important WTO members. In the research, we will try to determine the EU's position on WTO reform, compare it with other major players and forecast the possible outcomes how and in what fields the reform will be carried out.

The research question of this study is: How is the EU taking the leading role in reshaping the future of the WTO? This research question can be widened: How is the EU taking the leading role in efforts to give concrete proposals, solutions and measures for overcoming the WTO crisis and modernizing the work of the WTO? A qualitative analysis, along with the comparative method, will be used in this paper. We will also have a scientific explanation of the motives and intentions of the countries that have a strong voice in the WTO.

\section{LITERATURE REVIEW}

The WTO-based system of regulating international trade is fraught with many problems. The problems that burden the work of the WTO are very well addressed in Bohl (2009) and McDougall (2018) regarding the problems in the WTO dispute settlement mechanism, Martin and Mercurio (2017) tackling the problems in the Doha Round of negotiations, Zagashvili (2019) about crises in the WTO as a manifestation of globalisation crises, and others.

At the beginning of the new century, scientific and professional circles have already expressed their views on the need for WTO reform. In Labonté 
(2002), the findings suggest that assistance and resources must be made available to poorer nations and jurisdictions of the WTO Agreements need to be restrained in order to be subordinated to human development and environmental sustainability goals. Gathii (2004) argued the importance of removing obstacles for developing countries' involvement in the governance of the WTO. Hauser and Zimmerman (2003) have suggestions on how to reform the WTO dispute settlement understanding. Hoekman (2011) summarizes the arguments and proposals to reform the modus operandi of the WTO, including decision-making procedures, negotiating modalities, and dispute settlement. The paper of Birkbeck (2009) explores options for improving the negotiation process, institutional reform of the WTO, and calls for the WTO to take greater leadership on the issues of trade, finance, aid for trade, and surveillance of protectionist measures. In his work, Crombrugghe (2009) states that a reform of the WTO is severely needed, and positive reform can be achieved. In Caporal and Gerstel (2018), we can find answers to questions like why are countries calling for WTO reform and what reform proposals are being suggested. Wilkinson (2019) is giving arguments on why the change in the WTO has to occur.

About the EU role in the WTO, we can find in Steinberger's (2006) conclusion that both the EU and the EU Member States are fully bound by all Treaty provisions, and are both, at the same time, fully responsible for each breach of the contract, no matter whether it was committed by an organ of the EU or an EU Member. De Búrca and Scott's (2000) research gives points of comparison and contrast between the EU and the WTO and how procedural norms at the WTO level are relevant for the EU decision-making bodies. Krämer-Hoppe's (2020) book provides a reconsideration of the positive and negative integration paradigm in the EU and the WTO.

Also, it would be useful to read about the role of new rising powers in global economic governance and about building their influence in the WTO. We can find out about the rise of the BRICs in relation to the Washington Consensus in Ban and Blyth (2013), and about different paths of Brazil, India and China at the WTO in Hopewell (2015). Narlikar's (2003) book analyses the coalition strategies of developing countries in the context of international trade, while Gaskarth (2016) focuses on China's and India's rise and offers answers on whether their growth is signalling a shift in power from the West to the East.

This paper will focus on the views and position of the EU in order to show the steps the EU is taking to reach a leadership position in the WTO. The scientific contribution of this paper will be a comparison of EU 
proposals for WTO reform with the proposals of four countries - China, the US, Canada and Japan. In this paper, we will explain, summarize and shine the light on the extensive and often inconspicuous documentation of the EU. This paper further analyses and compares the requirements for WTO reforms set by its most influential members, explaining their differences and motives, thus very clearly pointing out the causes of the blockade and the uncertain future of this organization.

\section{THE EU-WTO RELATIONSHIP}

Both the EU and the individual $27 \mathrm{EU}$ countries are members of the WTO. The Ministerial Conference is the WTO's highest decision-making body, and the EU Trade Commissioner represents the EU in the WTO's Ministerial Conference. Thus, the European Commission alone speaks for the EU at almost all WTO meetings. Besides the US, the EU has always been the main protagonist and a crucial player in multilateral trade negotiations, starting with the GATT through the WTO (see Table 1).

TABle 1: The EU ROLE IN GATT AND WTO

\begin{tabular}{|l|l|}
\hline $\begin{array}{c}1947 \text { General Agreement on Tariffs } \\
\text { and Trade (GATT) }\end{array}$ & \multicolumn{1}{c|}{$\begin{array}{c}1995 \text { World Trade Organization } \\
\text { (WTO) }\end{array}$} \\
\hline $\begin{array}{l}\text { - EU single market was partly inspired } \\
\text { by GATT principles and practice } \\
\text { (many of the EC Treaty provisions } \\
\text { reflect this) }\end{array}$ & $\begin{array}{l}\text { The EU promotes a multilateral } \\
\text { framework for trade negotiations, } \\
\text { intended to complement bilateral } \\
\text { negotiations }\end{array}$ \\
$\begin{array}{l}\text { The EU reduced its common external during rounds of negotiations } \\
\text { tariff }\end{array}$ & $\begin{array}{l}\text { The EU has been one of the biggest } \\
\text { users of the WTO dispute settlement } \\
\text { system } \\
\text { - Because of the stalemate in the Doha } \\
\text { Round, the EU reconsidered its long- } \\
\text { standing strategy and returned to } \\
\text { regional and bilateral negotiations. } \\
\text { - The EU is exploring the possibility of } \\
\text { modernizing the WTO }\end{array}$ \\
\hline
\end{tabular}

Source: Author according to the EU and the WTO, 2020. 
Among the countries that ratified the WTO Agreement as early as 1995 were the EU, the US, Japan, and Canada. At that time, they had a $90 \%$ share in world trade (Jelisavac Trošić, 2015, p. 44). In the WTO practice, all significant proposals are submitted by developed countries, most often by the four powerful member states: the EU, the US, Japan, and Canada (which are known as the 'Quadrilaterals' or the 'Quad'). Over time, other countries appeared with a stronger voice: India, Australia and Brazil (they were called 'the new Quad', the 'Four/Five Interested Parties' (FIPS), the 'Quint' and the 'G-6'). They tried to break the Doha Round deadlocks, but the Round was suspended in July 2006 because the six could not agree.

According to formal views, 'the EU is a strong supporter of the multilateral trading system. Having exclusive competence in trade policy, the EU plays a key role in the WTO and actively promotes a multilateral trading system that is fair, predictable and based on common rules' (Permanent Mission of the EU to the WTO, 2016). The EU has always promoted international trade based on the rule of law. The EU advocates for the multilateral introduction of rules in trade, but on the other hand, it has given insufficient concessions for its highly protected trade in agricultural products.

A new strategic agenda for the EU 2019-2024 sets out the priority areas to provide guidance for the work of the European Council and other EU institutions. The strategic agenda focuses on four main priorities:

1. Protecting citizens and freedoms;

2. Developing a strong and vibrant economic base;

3. Building a climate-neutral, green, fair and social Europe;

4. Promoting European interests and values on the global stage (European Council, 2019a).

Under the fourth priority, we can find guidance and recommendations for pursuing robust trade in line with multilateralism and the global rulesbased international order. Under this priority, the Council has agreed, for the key actions on 'ensuring ambitious and robust trade policy, within the reformed WTO and at the bilateral level between the EU and its partners cooperating closely with NATO' (European Council, 2019b).

The EU set six priorities for 2019-2024, which will serve to address the political, economic, or social challenges faced by the EU and its citizens:

1. A European Green Deal;

2. A Europe fit for the digital age; 
3. An economy that works for people;

4. A stronger Europe in the world;

5. Promoting our European way of life;

6. A new push for European democracy (European Commission, 2019a).

In the fourth priority - A stronger Europe in the world - the European Commission has compiled a first set of ideas to modernize the WTO. These ideas relate to three key areas:

1. Updating the rule book on international trade to capture today's global economy;

2. Strengthening the monitoring role of the WTO;

3. Overcoming deadlock on the WTO dispute settlement system (European Commission, 2019b).

It is clear that during all the years after the Second World War, the EU actively participated in building multilateral rules for regulating international trade. So far, the EU has played a central role in developing the international trading system. It can also be concluded that the EU will not easily give in to the dissolution or disappearance of the WTO, but will make an effort to reform and modernize the WTO in the coming years.

\section{THE EU'S POSITION ON WTO REFORM}

The European Commission has proposed improving the functioning of the WTO in areas that it recognizes and considers crucial. The EU is an advocate of multilateral trade regulation and advocates that the WTO has to ensure free and fair trade. The EU proposes three areas for modernization: area 1 - rulemaking and development; area 2 - regular work and transparency; area 3 - dispute settlement. For each area, the EU has whole sets of measures and concrete modernization proposals (see Table 2). 
TABLE 2: EU PROPOSALS ON WTO MODERNIZATION

\begin{tabular}{|c|c|c|}
\hline $\begin{array}{c}\text { Rulemaking } \\
\text { and development }\end{array}$ & $\begin{array}{c}\text { Regular work } \\
\text { and transparency }\end{array}$ & $\begin{array}{c}\text { Dispute } \\
\text { settlement }\end{array}$ \\
\hline $\begin{array}{l}\text { Proposals for future } \\
\text { rulemaking activities } \\
\text { in the WTO } \\
\text { A. Creating rules that } \\
\text { rebalance the system and } \\
\text { level the playing field } \\
\text { B. Establishing new rules } \\
\text { to address barriers to } \\
\text { services and investment, } \\
\text { including in the field of } \\
\text { forced technology } \\
\text { transfer } \\
\text { C. Addressing the } \\
\text { sustainability objectives } \\
\text { of the global community }\end{array}$ & $\begin{array}{l}\text { Transparency } \\
\text { and notifications } \\
\text { A. More effective } \\
\text { committee-level } \\
\text { monitoring } \\
\text { B. Incentives for } \\
\text { improving notification } \\
\text { compliance } \\
\text { C. Sanctions for willful } \\
\text { and repeated non- } \\
\text { compliance } \\
\text { D. Counter-notifications } \\
\text { E. Strengthening the } \\
\text { Trade Policy Review } \\
\text { Mechanism (TPRM) }\end{array}$ & $\begin{array}{l}\text { First stage: } \\
\text { comprehensive } \\
\text { amendment of the } \\
\text { provisions of the } \\
\text { Dispute Settlement } \\
\text { Understanding (DSU) } \\
\text { relating to the } \\
\text { functioning of the } \\
\text { Appellate Body } \\
\text { addressing all points } \\
\text { of concern with the } \\
\text { "approach" of the } \\
\text { Appellate Body } \\
\text { A. Article } 17.5 \text { of the DSU } \\
\text { and the issue of } 90 \text { days } \\
\text { B. Transitional rules for } \\
\text { the outgoing Appellate } \\
\text { Body members } \\
\text { C. Findings unnecessary } \\
\text { for the resolution of the } \\
\text { dispute } \\
\text { D. The meaning of } \\
\text { municipal law as the } \\
\text { issue of fact } \\
\text { E. The issue of precedent } \\
\text { F. Independence of the } \\
\text { Appellate Body members }\end{array}$ \\
\hline $\begin{array}{l}\text { Proposals for a new } \\
\text { approach to flexibilities } \\
\text { in the context of } \\
\text { development objectives } \\
\text { A. Graduation } \\
\text { B. Special and Differential } \\
\text { Treatment (SDT) in a } \\
\text { future agreement } \\
\text { C. Additional SDT in } \\
\text { existing agreements }\end{array}$ & $\begin{array}{l}\text { Solving market } \\
\text { access problems } \\
\text { A. Developing rules that } \\
\text { oblige Members to give } \\
\text { substantive replies } \\
\text { B. Strengthening cross- } \\
\text { committee coordination } \\
\text { on market access issues }\end{array}$ & $\begin{array}{l}\text { Second stage: addressing } \\
\text { substantive issues } \\
\text { A. The substantive rules } \\
\text { as such can be modified } \\
\text { or interpreted by the } \\
\text { WTO Membership in } \\
\text { accordance with the } \\
\text { relevant procedures } \\
\text { B. Discussions on possible } \\
\text { changes or authoritative } \\
\text { interpretations }\end{array}$ \\
\hline
\end{tabular}




\begin{tabular}{|l|l|l|}
\hline \multicolumn{1}{|c|}{$\begin{array}{c}\text { Rulemaking } \\
\text { and development }\end{array}$} & \multicolumn{1}{|c|}{$\begin{array}{c}\text { Regular work } \\
\text { and transparency } \\
\text { Adjusting the WTO } \\
\text { the procedural aspects of } \\
\text { the WTO's rulemaking } \\
\text { activities }\end{array}$} & $\begin{array}{c}\text { Dispute } \\
\text { settlement }\end{array}$ \\
$\begin{array}{l}\text { A. Multilateral } \\
\text { negotiations }\end{array}$ & \\
B. Plurilateral & \\
negotiations & \\
C. Role of the secretariat & & \\
D. Building political & & \\
support & & \\
\hline & & \\
& Downsizing ineffective & \\
\hline
\end{tabular}

Source: Author according to European Commission Concept paper, 2018.

The EU is taking a leading role in working towards the WTO modernization with the goal to establish a system that can solve the challenges of today's global economy and work again for all members. The EU has already begun cooperation with other countries, with the US and Japan in trilateral discussions, with China in a special working group, and with other G20 partners.

A WTO structural reform and levelling the playing field in global trade is a proclaimed key priority for the EU. It encourages China to opt-out of the special and differential treatment, and to accept strengthening the rules on government subsidies. The EU calls for flexibility in terms of negotiation modalities in the Doha Round. When there is no interest of all countries in certain issues, it should be allowed to move forward in the negotiations in order to achieve plurilateral agreements within the WTO, for instance, on digital trade, or services and investment. The EU wants a gradual reform of the entire system, the continuation of the multilateral settlement of trade disputes, as well as multilateral negotiations with the introduction of certain changes that would lead to new modern WTO agreements. The EU has presented the comprehensive reform proposals involving substantial changes in the WTO.

In order to hold a leadership position, reforming the WTO must remain a top priority for the EU. Predictable and transparent rules and their 
enforcement are indispensable for the EU, so it tries to uphold the rulesbased trading system. "The EU will always believe in the strength and value of multilateralism and cooperating in global institutions. We will propose a Joint Communication on strengthening the EU's contribution to rules-based multilateralism. We need to lead reforms of the World Health Organization and World Trade Organization to make them fit for new realities' (European Commission, 2020a, p. 6).

\section{Comparison with the US's position}

The US agrees with most of the EU and Canada proposals, except for the proposals on resolving the stalemate in the Appellate Body (EU) and seeking a conciliatory solution between all WTO member countries (Canada). 'The US is working through various WTO standing committees to advance reform ideas. To remain a viable institution that can fulfil all facets of its work, the WTO must focus its work on structural reform, find a means of achieving trade liberalization between Ministerial Conferences and adapt to address the challenges faced by traders today' (USTR, 2020, p. 152). In reform proposals, the US relies on continuing and expanding an America-First trade agenda. The US is in favour of establishing new rules in the WTO, directly criticizing China and claiming that China, as a nonmarket economy, is no longer compatible with the WTO system.

The US seeks the Appellate Body reform and reform of special and differential treatment for developing countries, a new fishery and a digital commerce agreement, enforcing notifications obligations, etc. The US's plan to reduce the number of countries eligible for special and differential treatment directly and, primarily, affects China and India. Current and future negotiations should deny this treatment to countries classified by the World Bank as high-income countries, the OECD countries, G20, as well as any country with 0.5 or more percentages of participation in world trade (Blenkinsop 2019). The US argues that far strict global rules on state-owned enterprises are needed, supported by a binding dispute resolution that allows for retaliation when rules are violated (Ibidem). The US is planning to explore a broader WTO reset since outdated tariff determinations no longer reflect economic realities. It is pushing for a close review of the WTO's budget, especially Appellate Body member salaries. 'The US will advocate for changes that allow for additional and more effective plurilateral agreements since there is an urgent need for a new political and legal understanding at the WTO that enables the pursuit of less-than-fully 
multilateral outcomes while preserving the characteristics of the WTO' (USTR, 2020, p. 19).

\section{Comparison with China's position}

China supports efforts to implement the necessary WTO reform and actively works with all parties to help cope with the current crisis and respond to the needs of the modern world, protect the multilateral trading system and promote the building of an open world economy. The necessary reform should cover the following four areas:

1. Resolving the crucial and urgent issues threatening the existence of the WTO;

2. Increasing the WTO's relevance in global economic governance;

3. Improving the operational efficiency of the WTO;

4. Enhancing the inclusiveness of the multilateral trading system (Delegation of China, 2019).

The Chinese proposal for each area contains specific steps that should be taken (see Table 3). We can assess that the Chinese proposal is designed to address the WTO survival crisis, increase its authority and efficiency and relevance in global economic governance.

TABLE 3: CHINA'S PROPOSAL ON WTO REFORM

\begin{tabular}{|c|c|c|c|}
\hline $\begin{array}{l}\text { Resolving the } \\
\text { crucial and urgent } \\
\text { issues threaten- } \\
\text { ing the existence } \\
\text { of the WTO }\end{array}$ & $\begin{array}{c}\text { Increasing } \\
\text { WTO's relevance } \\
\text { in global } \\
\text { economic } \\
\text { governance }\end{array}$ & $\begin{array}{l}\text { Improving the } \\
\text { operational } \\
\text { efficiency } \\
\text { of the WTO }\end{array}$ & $\begin{array}{c}\text { Strengthening } \\
\text { the inclusiveness } \\
\text { of the } \\
\text { multilateral } \\
\text { trading system }\end{array}$ \\
\hline $\begin{array}{l}\text { Breaking the } \\
\text { Impasse of the } \\
\text { Appointment } \\
\text { Process of } \\
\text { Appellate } \\
\text { Body members }\end{array}$ & $\begin{array}{l}\text { Rectifying the } \\
\text { Inequity in Rules } \\
\text { on Agriculture }\end{array}$ & $\begin{array}{l}\text { Improving the } \\
\text { Compliance of } \\
\text { Notification } \\
\text { Obligation }\end{array}$ & $\begin{array}{l}\text { Respecting the } \\
\text { Right of Special } \\
\text { and Differential } \\
\text { Treatment of } \\
\text { Developing } \\
\text { Members }\end{array}$ \\
\hline $\begin{array}{l}\text { Tightening } \\
\text { Disciplines to } \\
\text { Curb the Abuse of } \\
\text { National Security } \\
\text { Exception }\end{array}$ & $\begin{array}{l}\text { Improving Trade } \\
\text { Remedies Rules }\end{array}$ & $\begin{array}{l}\text { Improving the } \\
\text { Efficiency of WTO } \\
\text { Subsidiary Bodies }\end{array}$ & $\begin{array}{l}\text { Adhering to the } \\
\text { Principle of Fair } \\
\text { Competition in } \\
\text { Trade and } \\
\text { Investment }\end{array}$ \\
\hline
\end{tabular}




\begin{tabular}{|l|l|l|l|}
\hline $\begin{array}{c}\text { Resolving the } \\
\text { crucial and urgent } \\
\text { issues threaten- } \\
\text { ing the existence } \\
\text { of the WTO }\end{array}$ & $\begin{array}{c}\text { Increasing } \\
\text { WTO's relevance } \\
\text { in global } \\
\text { economic } \\
\text { governance }\end{array}$ & $\begin{array}{c}\text { Improving the } \\
\text { operational } \\
\text { efficiency } \\
\text { of the WTO }\end{array}$ & $\begin{array}{c}\text { Strengthening } \\
\text { the inclusiveness } \\
\text { of the } \\
\text { multilateral } \\
\text { trading system }\end{array}$ \\
\hline $\begin{array}{l}\text { Tightening } \\
\text { Disciplines to } \\
\text { Curb Unilateral } \\
\text { Measures } \\
\text { Inconsistent } \\
\text { with WTO Rules }\end{array}$ & $\begin{array}{l}\text { Accelerating } \\
\text { Negotiations } \\
\text { on Fisheries } \\
\text { Subsidies }\end{array}$ & $\begin{array}{l}\text { Advancing Joint } \\
\text { Initiative on } \\
\text { Trade-related } \\
\text { Aspects of } \\
\text { E-commerce } \\
\text { in an Open and } \\
\text { Inclusive Manner }\end{array}$ & \\
\hline & $\begin{array}{l}\text { Promoting } \\
\text { Discussions } \\
\text { on New Issues }\end{array}$ & & \\
\hline
\end{tabular}

Source: Author according to China's proposal on WTO reform, 2019.

The Chinese proposal largely coincides with the EU's proposal, as both recommend strengthening the implementation of the WTO member countries' commitments on trade policy information in order to improve the organization's efficiency. On the other hand, opposing the EU proposal, China seeks to retain the right to special and differential treatment for developing countries, arguing that without it, liberalization would not benefit those countries. The Chinese position regarding state-owned enterprises is that they should not be suppressed and limited, but it is necessary to provide equal conditions for enterprises of different ownership for market competition (Jelisavac Trošić, 2020, p. 162). The proposal sends a clear message of China's opposition to the US agenda that individually targets China.

\section{Comparison with Japan's position}

Japan has many close ties and is one of America's most important allies. Japan also shares one of the world's largest bilateral economic relationships 
with China. That puts Japan in a unique position to navigate between the two. In its efforts to contribute to the WTO modernization, Japan does not work or act much independently but cooperates on issues of their interest with other member countries. Considering that Japan is a developed economy, in their interest is to cooperate with the EU and the US, especially on the regulation of technologically advanced forms of trade.

The EU, the US and Japan announced their agreement to strengthen existing rules on industrial subsidies, condemned forced technology transfer practices, and confirmed continued cooperation on a number of key items such as:

- The importance of market-oriented conditions;

- Reform of the WTO, to include increasing compliance with the existing WTO notification obligations;

- Pressing the advanced WTO members claiming a developing country status to undertake a full commitment in the ongoing and future WTO negotiations;

- International rulemaking and trade-related aspects of electronic commerce at the WTO; and

- International forums such as the Global Forum of Steel Excess Capacity and the Governments/Authorities' Meeting on Semiconductors (European Commission, 2020b, p. 1).

Japan will not directly confront China and will follow the EU leadership since it suits their interests.

\section{Comparison with Canada's position}

Canada proposes a range of instruments that could be used to gradually modernize and strengthen the WTO. In most cases, these are solutions that do not involve changes to the existing WTO agreements. These include actions and measures to:

1. Improve the efficiency and effectiveness of the monitoring function;

2. Safeguard and strengthen the dispute settlement system; and,

3. Lay the foundation for modernizing the substantive trade rules when the time is right (WTO, 2018, p. 1).

Canada insists on pragmatic and realistic actions and confidencebuilding measures. Canada argues that it is unrealistic to expect a new multilateral agreement or significant institutional changes in the near future. 
Most of the proposed Canada's solutions require changes to the existing agreements or formal institutional reform. In fact, most of Canada's proposals can be achieved with alternative instruments that will act gradually and flexibly. The most necessary and urgent action would be aimed at restoring the function of dispute settlements, and after the function of monitoring. In this way, trust in trade according to the adopted rules would be restored, and the success of these actions would bring a positive momentum for the continuation of negotiations and the adoption of new rules (Jelisavac Trošić, Todić, Stamenović, 2018, p. 247).

Both the EU and Canada argue that consensus decision-making is outdated, advocate changing the system of special and differential treatment, and specifically target China for introducing new disciplines in subsidies and state-owned enterprises, while at the same time largely keeping silent about violations committed by the US.

\section{EU, US, China, Japan, Canada - What the future holds for the WTO?}

The multilateral negotiation system embodied in the WTO has its limits. One of them is that any member can block progress because of the need for consensus. The WTO is in existential crisis as a result of the Doha Round's failure to end in success (Jelisavac Trošić, 2017, p. 244). There is a wide spectrum of issues and topics under the WTO negotiations, and the members should negotiate in good faith. But, for instance, protectionism in agriculture, despite its steadily declining percentage of world trade, is still a stumbling block for negotiations.

Most reform proposals have been made in the areas of trade negotiations, trade policy monitoring, and dispute resolution. It seems now that there is a consensus on the need for reform, but there are a lot of disagreements on how and what to reform, where to start, what are priorities, etc. Initial concrete proposals for WTO reform were given by developed countries and it is noticeable that developing countries are not so actively engaged in the process of reforming. The most comprehensive of the proposals is the EU proposal. From the developing countries, only China is currently included in the WTO reform talks. However, it is questionable to what extent China, with high rates of economic and trade growth, can be called a developing country and really protect the interests of that group.

At the moment, it is very difficult to predict how the reform will unroll. For now, the distance between the policy positions of the three biggest 
players in international trade - the EU, the US and China - remains significant, in particular on rules for subsidies and state aid. The solutions that will be adopted after the negotiations between the major players will have a decisive and long-term impact on the individual trade development policies of countries, and indirectly, on the overall economic development, regardless of whether they directly participated in negotiations and formulations. Today, there is the new trade environment, and there are some that question the WTO's continuing ability to help shape the future of the international trade landscape and consider the idea that the organization might essentially act merely as an umbrella for trade negotiations in the future (Martin, Mercurio, 2017, p. 56).

Over the past decades, the EU and the US acted as a world regulator. They were defining the rules of multilateral trade, and developing countries implemented those rules. Rising powers, China, India and Brazil, took a more proactive position and challenged the old global trade order. Now, the EU and the US, each in their own way, want to take the lead in the WTO again. The EU peculiarly displayed a preference for regulatory agreements, such as investment, competition, environment, and labour, to be an integral part of international agreements (De Bièvre, 2006, p. 853). The EU proposal is the most comprehensive of all proposals, with numerous concrete proposals on specific problems in the work of the WTO and shows the intention of the EU to become an old-new world trade regulator.

\section{CONCLUSION}

The WTO member countries have started working individually to make proposals for solving many problems of this organization, and discussions are underway. Some initiatives have been launched, and proposals have been made to overcome the crisis, so it remains to find a compromise in the coming years, with the agreement of the most influential members, including the EU, which would lead to the reform and modernization of the WTO.

How is the EU taking the leading role in reshaping the future of the WTO? The EU has taken an active role in what it calls modernization and reform of the WTO. Indicators that the EU is taking the leading role are:

- The European Commission issued on 18 September 2018 the Concept paper on WTO modernization;

- In the Work Programme 2021, the Commission announced its intention to lead reforms of the WTO; 
- The EU is taking the key actions on ensuring ambitious and robust trade policy, within the reformed WTO;

- The EU actively cooperates with other key players, primarily with the US and Japan, but also with China on issues where they can find a common solution;

- From all the WTO reform proposals made so far, the EU proposal was the most elaborated and served as a basis for proposals from other countries.

Consultations among influential players are on the way. In addition to the US, China and other WTO members have been strengthened, so the EU is facing a difficult path to achieve its plans and reshape the WTO according to its intentions. The EU is trying to lead and play a diplomatic role in order to identify potential solutions, which will be very hard given the opposing views of the main actors. Also, the list of necessary changes in the system of this international organization is long. The best chance of success has a clear strategic direction for change and a deep EU engagement with China and the US. There are a lot of uncertainties in trade today, and unless the WTO reforms, it loses its significance and integrity. Through actions, the EU seeks to strengthen the capacities of this organization and regain a leading position within its framework. Also, judging by all the stating positions and EU plans, it is clear that reforming the WTO will take time.

\section{REFERENCES}

Ban, C., Blyth, M. (2013). The BRICS and the Washington Consensus: An Introduction, Review of International Political Economy. 20(2). 241-255.

Birkbeck, C. D. (2009). Reinvigorating debate on WTO reform: the contours of a functional and normative approach to analyzing the WTO system, in: Debra P. Steger (ed) Redesigning the World Trade Organization for the Twenty-first Century (pp. 11-40), Ottawa, CIGI and Wilfrid Laurier University Press.

Blenkinsop, P. (2019, December 10). U.S. trade offensive takes out WTO as global arbiter. Reuters, retrieved from https://www.reuters.com/ article/us-trade-wto/us-trade-offensive-takes-out-wto-as-globalarbiter-idUSKBN1YE0YE. Accessed 10 January 2021.

Bohl, K. (2009). Problems of developing country access to WTO dispute settlement. Chi.-Kent J. Int'l \& Comp. L., 9(1). 
Caporal, J., Gerstel, D. (2018). WTO Reform: The Beginning of the End or the End of the Beginning?. Saatavilla. Centre for Strategic and International Studies.

Chorev, N., Babb, S. (2009). The Crisis of Neoliberalism and the Future of International Institutions: A Comparison of the IMF and the WTO. Theory and society 38(5). 459-484.

Ciuriak, D. (2019). The US-China Trade War: Technological Roots and WTO Responses. Global Solutions Journal 4. 130-135.

Crombrugghe, A. de. (2009). Opportunities of reforming the WTO: Resistance and potentials of change. Public Organization Review, 9(2), 139-156.

De Bièvre, D. (2006). The EU regulatory trade agenda and the quest for WTO enforcement. Journal of European Public Policy. 13(6) pp. 851-866.

De Búrca, G., Scott, J. (2000). The Impact of the WTO on EU Decision-making. Harvard, Harvard Law School.

Delegation of China. (2019, May 13). China's proposal on WTO reform. Beijing.

European Commission. (2018, September 18). WTO modernization, Introduction to future EU proposals, Concept paper, Brussels.

European Commission. (2019a, July 16). The European Commission's priorities, retrieved from https://ec.europa.eu/info/strategy/priorities2019-2024_en. Accessed 11 November 2020.

European Commission. (2019b, August 29). The EU's objectives, retrieved from https://ec.europa.eu/trade/policy/eu-and-wto/. Accessed 11 January 2021.

European Commission. (2020a, October 19). Commission Work Programme 2021, Brussels.

European Commission. (2020b, January 14). Trade/WTO: EU, U.S. and Japan agree on new ways to strengthen global rules on industrial subsidies, Brussels.

European Council. (2019a, June 21). A new strategic agenda for the EU 20192024, retrieved from https://www.consilium.europa.eu/en/eustrategic-agenda-2019-2024/. Accessed 29 November 2020.

European Council. (2019b, June 21). Promoting Europe's interests and values in the world, retrieved from https:/ / www.consilium.europa.eu/en/eustrategic-agenda-2019-2024/\#group-EU-in-the-world-zh3uey0ErW. Accessed 14 November 2020. 
Gaskarth, J. (2016). China, India and the Future of International Society. London, Roman and Littlefield.

Gathii, J. T. (2004). Process and Substance in WTO Reform. Rutgers L. Rev., $56,885$.

Hauser, H., Zimmerman, T. A. (2003). The challenge of reforming the WTO dispute settlement understanding. Intereconomics, 38(5), 241-245.

Hoekman, B. (2011). Proposals for WTO reform: A synthesis and assessment. The World Bank.

Hopewell K., (2015). Different Paths to Power: The Rise of Brazil, India and China at the World Trade Organization, Rev. Int'l Pol. Economy. 22(2). pp. 311-338.

Jelisavac Trošić S. (2017). Challanges to Ensure that the Regulatory Framework Keeps Up with Changes in the Global Trade, in: Branislav Đorđević, Taro Tsukimura, Ivona Lađevac (eds.), Social and Economic Problems and Challenges in the Contemporary World (pp. 234-254). Japan, Belgrade, Global Resource Management, Doshisha University, IIPE.

Jelisavac Trošić S., Todić, D., Stamenović, M. (2018). Svetska trgovinska organizacija, životna sredina i sistem zdravstvene zaštite. Beograd, Institut za međunarodnu politiku i privredu.

Jelisavac Trošić, S. (2015). Pregovori u okviru GATT i STO. Beograd, Institut za međunarodnu politiku i privredu.

Jelisavac Trošić, S. (2020). Trgovinski rat između Sjedinjenih Američkih Država i Kine i urušavanje Svetske trgovinske organizacije. Nacionalni interes (National Interest), 38(2) DOI:https:doi.org/10.22182/ni.3822020.8, pp. 145-171.

Krämer-Hoppe, R. (2020) Positive Integration-EU and WTO Approaches Towards the Trade and Debate. Springer.

Labonté, R. (2002). International governance and World Trade Organization reform. Critical Public Health, 12(1), 65-86. doi: 10.1080/095815901 10113312.

Martin, A., Mercurio, B. (2017). Doha dead and buried in Nairobi: lessons for the WTO. Journal of International Trade Law and Policy. 16(1). pp. 4966. doi: 10.1108/JITLP-01-2017-0001.

McDougall, R. (2018). The crisis in WTO dispute settlement: Fixing birth defects to restore balance. Journal of World Trade. 52(6).

Narlikar, A. (2003). International Trade and Developing Countries: Bargaining Coalitions in the GATT \& WTO. Routledge. 
Permanent Mission of the EU to the WTO. (2016, May 11). The EU Mission to the WTO, retrieved from https://eeas.europa.eu/delegations/ world-trade-organization-wto/1225/eu-mission-wto_en. Accessed 25 November 2020.

Steinberger, E. (2006). The WTO Treaty as a Mixed Agreement: Problems with the EC's and the EC Member States' Membership of the WTO. European Journal of International Law, 17(4), 837-862.

USTR (Office of the United States Trade Representative). (2020). 2020 Trade Policy Agenda and 2019 Annual Report of the President of the United States on the Trade Agreements Program, Washington.

Wilkinson, R. (2019). Revisiting WTO Reform. WTO Reform: Reshaping Global Trade Governance for 21st Century Challenges, 7-19.

WTO. (2018, September 24). Strengthening and modernizing the WTO: discussion paper, Communication from Canada, JOB/GC/201.

WTO. (2021). Appellate Body, retrieved from https://www.wto.org/ english/tratop_e/dispu_e/appellate_body_e.htm. Accessed 21 January 2021.

Zagashvili, V.S. (2019). WTO Crisis as Manifestation of Globalization Crisis. Mirovaia ekonomika i mezhdunarodnye otnosheniia, 63(6), 5-12. 